\title{
Changes in structural heterogeneity and stand productivity by mixing Scots pine and Maritime pine
}

\author{
José Riofrío ${ }^{\mathrm{a}, *}$, Miren del Río ${ }^{\mathrm{a}, \mathrm{b}}$, Hans Pretzsch $^{\mathrm{c}}$, Felipe Bravo ${ }^{\mathrm{a}, \mathrm{d}}$ \\ a Sustainable Forest Management Research Institute, University of Valladolid \& INIA, Av. Madrid 44, Palencia 34004, Spain \\ ${ }^{\mathrm{b}}$ Department of Silviculture and Forest Management, INIA, Forest Research Centre, Ctra. A Coruña, km 7.5, Madrid 28040, Spain \\ ${ }^{c}$ Chair for Forest Growth and Yield Science, Technische Universität München, Hans-Carl-von-Carlowitz-Platz 2, D-85354 Freising, Germany \\ d Departamento de Producción Vegetal y Recursos Forestales, E.T.S de Ingenierías Agrarias, Universidad de Valladolid, Palencia, Spain
}

\section{ARTICLE INFO}

\section{Keywords:}

Mixing effects

Over-yielding

Stand structure

Tree allometry

Emergent properties

Vertical stratification

\begin{abstract}
A B S T R A C T
Mixed-species stands have been studied extensively due to their potentially superior productivity, multi-functionality benefits and high ecological value compared to pure stands. The higher structural heterogeneity in mixed stands that can emerge from species interactions could be linked to the relationship between species diversity and ecosystem functions. We tested whether changes in stand structure also occur in mixtures of species with similar traits and whether they explain over-yielding patterns. Based on research with 12 triplets of Scots pine (Pinus sylvestris L.) and Maritime pine (Pinus pinaster Ait.) in the northern Iberian Peninsula (Spain), we provide evidence that species mixing increased structural heterogeneity and may induce over-yielding in mixed-species stands compared to monospecific stands. In this mixture of two light-demanding species, we observed that (i) stand composition influenced the inter-specific crown allometric variation, (ii) structural heterogeneity in mixed stands was caused by both specie-specific traits and species interactions, and (iii) intraspecific and interspecific differences in both crown size plasticity and size-distribution differentiation were associated with the increased relative productivity of mixed stands. We detected that crown complementarity and vertical stratification in the canopy space is a crucial mechanism for enhancing ecosystem productivity in light-demanding species and could be related to light interception and light-use. This work improves our understanding of emerging properties in mixed stands and introduces considerations for properly scaling and tracing mixing effects at individual tree, size distribution and stand levels.
\end{abstract}

\section{Introduction}

Mixed-species forests are becoming more prominent in forest management due to increasing evidence of their greater potential to supply ecological and socio-economic goods and services, with respect to monospecific forests. A plausible comparison between mixed stands with neighboring pure stands makes it possible to detect positive or negative mixture effects. Combining tree- and stand-level analysis may help to determine which mixing effects are most important for forest functioning (Forrester and Pretzsch, 2015). Each organizational level provides special insights that are not attainable at the levels above or below. Additionally, research into size structure dynamics can link findings at individual tree and stand levels and thus contribute to tracing the effects of species mixing (Pretzsch and Schütze, 2016)
Stand structure is usually described in terms of stand density, size distribution, horizontal and vertical tree distribution patterns, or combinations of several attributes (Gadow et al., 2012; McElhinny et al., 2005). Mixing species with complementary structural and functional traits may enhance structural complexity above and below ground, which can increase stand productivity and resource efficiency compared to monocultures (Dănescu et al., 2016; Pretzsch, 2014; Pretzsch and Schütze, 2016). However, negative or non-significant effects have also been reported for structural diversity-productivity relationships (Bourdier et al., 2016).

Structural attributes such as crown morphology and the resulting canopy structure are pivotal drivers of stand dynamics, which may be key determinants of productivity and a broad range of ecosystem services (Gadow et al., 2012). This applies to mixed-species stands where inter- and intra-specific interactions may increase structural hetero-

\footnotetext{
* Corresponding author.

Email address: jgriofrio@hotmail.com (J. Riofrío)
} 
geneity (Pretzsch, 2014). Interspecific differences in morphological and physiological traits among coexisting species may enhance complementary mechanisms, such as the filling of canopy space, accumulating leaf area index (LAI), light capture and light use efficiency, all of which can contribute to explaining greater productivity in more diverse forests (Jucker et al., 2015; Larocque et al., 2013; Pretzsch, 2014; Toïgo et al., 2017; Williams et al., 2017). Recent studies have also uncovered evidence that intraspecific differences in allometric scaling of tree crowns in mixed stands were dependent on the competitive environment and competitive species composition in the stand (Forrester et al., 2017b; Pretzsch, 2014), which are directly related to canopy structure. In some mixtures, even small differences in species structural traits can trigger positive interspecific interactions through complementarity or competition reduction mechanisms (Jucker et al., 2014), but the role of differences in species-specific traits in mixed stands functioning is still non-well understood.

When mixed-species stands are more productive than monocultures, higher light absorption is often suggested as a cause. However, few studies have quantified this effect and even fewer have examined light-related interactions (Forrester et al., 2017a). A key question is whether differences in structural attributes between mixed and pure stands result from a merely 'additive effect', i.e. the combination of the different species-specific morphological traits in a mixed stand, or if species interactions trigger species traits that surpass their behavior in pure stands, modifying outcomes such as productivity, stability, and resistance, in a 'multiplicative effect' (Forrester and Pretzsch, 2015; Pretzsch, 2014). Multiplicative effects are highly relevant for understanding changes in forest functioning and for modelling and predicting mixed-stand dynamics and productivity (Forrester et al., 2017a; Pretzsch et al., 2016).

Research on interactions in mixed forests is often based on net effects due to the difficulty to isolate effects of from different mechanisms that influence interspecific interactions (Pretzsch and Schütze, 2009). However, growth and productivity at the stand level results from numerous interactions operating at the individual tree level, and therefore depends on the arrangement or distribution of competitive neighborhoods across a stand (Forrester and Pretzsch, 2015; Pretzsch et al., 2015b). In this study, we explored net mixing effects on productivity and stand structure in mixed forests composed of Scots pine (Pinus sylvestris L.) and Maritime pine (Pinus pinaster Ait.) in the Northern Iberian Range in Spain. These two main forest species in Spain grow in pure and mixed stands, either naturally or derived from species selection for afforestation. Riofrío et al., (2017b) identified large-scale positive interactions between these species when they coexist in mixtures, and suggested that light competition is the main driver limiting growth. These species show similar crown architecture (Poorter et al., 2012) and slight differences in shade tolerance (Gaudio et al., 2011; Sánchez-Gómez et al., 2006), thus slight or null mixing effects could be expected.

The main objective of this study was to analyze the mixture effects by comparing mixed stands with neighboring pure stands at three organizational levels - individual tree, tree size distribution, and stand - in order to infer possible complementarity mechanisms between these pine species with similar traits. Our hypothesis is that small differences in structural and functional traits between the two species under study and species interactions can induce changes in above-ground species allometries, crown dominance and stand structural traits. This would result in vertically structured canopies or crown complementarity among species in mixtures, that are related with the way light is distributed among trees. Changes in structural heterogeneity may be a mechanism that produces mixture effects on productivity in Mediterranean mixed-pine forests. To assess this hypothesis, we asked the follow working questions:
- Are tree crown allometric relationships affected by neighboring species composition?

- To what extent does mixing modify structural attributes at the stand and species levels compared to pure stands?

- How does volume production of mixed-species stands differ from that of neighboring pure stands?

- Are mixing effects on stand productivity related to structural heterogeneity?

\section{Materials and methods}

\subsection{Field site and study design}

The study was conducted in the Mediterranean mixed pine forests of Scots pine (Pinus sylvestris L.) and Maritime pine (Pinus pinaster Ait.) that cover approximately 50,000 ha in the Northern Iberian Range. This forest cover is divided in even-aged sections and compartments. The main objective is timber production, however, in recent years, other ecosystem services have gained great importance (Aldea et al., 2014). To achieve this objective, an even-aged management consisting of strip clear-cutting with soil movement and planted or sowing when necessary. Thinnings are common and not limited to self-financed interventions. In the study area mean annual temperature was $9.0^{\circ} \mathrm{C}$, mean annual precipitation ranged from 715 to $888 \mathrm{~mm}$, elevation ranged from 1090 to $1277 \mathrm{~m}$ a.s.l. Soils were acidic brown earths (pH 3.9-5.4) with sandy loam to sandy texture, low cation exchange capacity (2.4-18.1 $\mathrm{cmol}_{\mathrm{C}} \mathrm{kg}^{-1}$ ) and medium to lower water-retention capacity (1.5-18 $\mathrm{g} \mathrm{cm}^{-2}$ ) (Lopez Marcos et al., 2017).

A total of 36 plots, grouped into 12 triplets of mixed plots (PS,PT) and their corresponding pure plots of Scots pine (PS) and Maritime pine (PT) were established in 2014-2015 (Fig. S1). Plots within triplets had similar site conditions, age and density and belonged to the same management compartments where the same silviculture regime had been applied (Table S1); facilitating a pair-wise plausible comparison of mixed versus pure stands. The stands were approximately full stocked, stocked above $60 \%$ relative to or even exceed the maximum density, and none of the plots had been thinned for at least 10 years. In most of the triplets, both species were in the same age phase comparing monoculture and mixed-species stands, ranging from mature (45-50 years) to old stands (120-140 years). Site quality at age 100 years indicated moderate to low growth conditions according to specific curves of pure stands (Bravo-Oviedo et al., 2007; Rojo and Montero, 1996). Some variations in stand age and site conditions were tolerated among triplets in order to cover stand variability in the study area.

Each triplet consisted of three circular plots of $15 \mathrm{~m}$ radius, including one pure plot of Scots pine, one pure plot of Maritime pine and one mixed plot that contained both species. Mixed plots had varying individual tree mixtures and the mixing proportion between species had a combination of at least $75-25 \%$ of the total basal area. Pure plots were located within $1 \mathrm{~km}$ of the mixed plots. Pure plots stands were considered only when total basal area of the target species was higher than $90 \%$ and were used as reference to evaluate mixing effects on stand structure, growth and yield.

All stems $>7.5 \mathrm{~cm}$ in diameter were inventoried, positioned (' $x$, $y$ ' coordinates) and measured the diameter at breast height (d). For each tree total height $(h)$ and height to crown base ( $h c b$, base of the crown's lowest primary branch) were measured using a vertex hypsometer. A crown class was assigned to each tree (dominant, co-dominant, dominated and suppressed). Dendrometric variables at the tree and stand level were calculated from stand measurements (Table 1). All data treatment, calculations and analyses were performed in $\mathrm{R}(\mathrm{R}$ 
Table 1

Stand description of mixed-species and monospecific triplet plots.

\begin{tabular}{|c|c|c|c|c|c|c|c|c|}
\hline Composition & & $\begin{array}{l}\mathrm{N} \text { (trees } \\
\left.\mathrm{ha}^{-1}\right)\end{array}$ & $\begin{array}{l}\mathrm{dq} \\
(\mathrm{cm})\end{array}$ & $\begin{array}{l}\text { BA } \\
\left(\mathrm{m}^{2} \mathrm{ha}^{-1}\right)\end{array}$ & $\begin{array}{l}\text { ho } \\
\text { (m) }\end{array}$ & $\begin{array}{l}\mathrm{V} \\
\left(\mathrm{m}^{3} \mathrm{ha}^{-1}\right)\end{array}$ & $\begin{array}{l}\text { PAIV } \\
\left(\mathrm{m}^{3} \mathrm{ha}^{-1} \text { year }^{-1}\right)\end{array}$ & Prop. (\% BA) \\
\hline \multirow[t]{3}{*}{$P$. pinaster mixed } & Mean & 286 & 37.9 & 31.2 & 21.5 & 282.5 & 4.2 & 53.5 \\
\hline & Max & 538 & 48.0 & 49.3 & 26.9 & 429.3 & 7.0 & 67.0 \\
\hline & Min & 127 & 27.5 & 11.1 & 15.0 & 79.7 & 2.2 & 28.6 \\
\hline \multirow{3}{*}{$\begin{array}{l}P . \text { sylvestris } \\
\text { mixed }\end{array}$} & Mean & 398 & 29.5 & 26.7 & 20.2 & 237.4 & 2.8 & 46.5 \\
\hline & Max & 594 & 40.6 & 45.9 & 26.7 & 473.2 & 6.9 & 71.4 \\
\hline & Min & 241 & 20.5 & 13.0 & 15.0 & 86.3 & 0.9 & 33.0 \\
\hline \multirow[t]{3}{*}{ Total mixed } & Mean & 685 & & 57.9 & & 519.9 & 7.0 & \\
\hline & $\operatorname{Max}$ & 1103 & & 75.7 & & 700.2 & 9.2 & \\
\hline & Min & 523 & & 33.3 & & 234.3 & 4.4 & \\
\hline \multirow[t]{3}{*}{$P$. pinaster pure } & Mean & 724 & 33.1 & 59.3 & 19.0 & 476.7 & 6.9 & 98.7 \\
\hline & $\operatorname{Max}$ & 1259 & 40.3 & 70.3 & 22.5 & 632.6 & 9.2 & 100.0 \\
\hline & Min & 410 & 22.0 & 37.5 & 14.9 & 249.6 & 4.2 & 95.0 \\
\hline \multirow[t]{3}{*}{ P.sylvestris pure } & Mean & 709 & 30.8 & 50.3 & 21.5 & 453.3 & 5.8 & 94.3 \\
\hline & $\operatorname{Max}$ & 1217 & 39.3 & 33.3 & 25.7 & 652.8 & 11.3 & 100.0 \\
\hline & Min & 410 & 21.5 & 66.3 & 16.5 & 236.4 & 3.1 & 83.3 \\
\hline
\end{tabular}

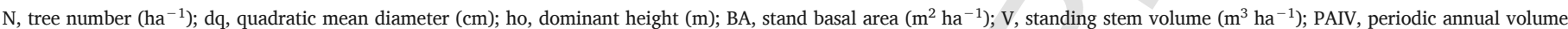

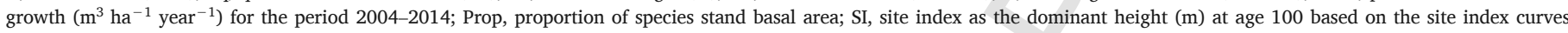
developed by Rojo and Montero (1996) and Bravo-Oviedo et al. (2007) for Scots pine and Maritime pine, respectively.

Develomment Core Team, 2015); the specific packages used are mentioned in each section.

Increment cores at stem height of $1.30 \mathrm{~m}$ were taken from most trees, covering at least the last 15 years, and avoiding dead or suppressed trees. A total of 736 from Scots pine and 693 from Maritime pine trees in mixed and pure plots were sampling. All cores were mounted, sanded till tree-ring boundaries were clearly visible and scanned at 1800 ppi image resolution. For each cored tree, tree ring widths $\left(\mathrm{mm} \mathrm{year}^{-1}\right)$ were dated and measured from the scanned images using the 'measuRing' package (Lara et al., 2015). The quality of cross-dating and synchronization of the growth series were assessed using the 'dplR' package (Bunn, 2010).

\subsection{Data preparation and backdating}

We set the evaluation period from 2004 to 2014 ( $t=11$ years). To evaluate the effect of mixing species on stand volume growth, diameters and heights had to be reconstructed for all trees for the beginning of this period (t). Diameter over bark at breast height in 2004 was calculated using the increment cores collected. The diameter increments of all non-cored trees for this evaluation period were calculated by fitting diameter increment functions for each plot and species. This is described more fully in Appendix A.

Specific height-diameter functions (Lizarralde, 2008) were used to reconstruct individual tree heights, which were parameterized for the same study region. This required estimates of past dominant heights, which were calculated from species-specific site index curves developed by Rojo and Montero (1996) and Bravo-Oviedo et al., (2007) for Scots pine and Maritime pine, respectively.

Individual tree diameter and height reconstruction data and species-specific volume functions (Rodreguez and Broto, 2014) were used to estimate stand volume (V), annual volume increment $\left(\mathrm{PAIV}=\left(\mathrm{V}-\mathrm{V}_{2004}\right) / \mathrm{t}\right)$ and annual basal area increment $\left(\mathrm{PAIBA}=\left(\mathrm{BA}-\mathrm{BA}_{2004}\right) / \mathrm{t}\right)$. Removed volume and basal area from the stand were not considered since the triplets were established in stands that had not been thinned during the study period at least. In pure plots, stems of the complementary species were assigned as Scots pine or Maritime pine, respectively.

\subsection{Stand structure}

In order to characterize structural traits and compare mixed and monospecific stands, we considered a set of attributes related to hori- zontal size distribution patterns and vertical structure as measures of stand structure (Pretzsch and Schütze, 2016), as well as quadratic mean diameter and dominant height. For analyzing differences in the shape of the respective size distributions, we calculated the mean, minimum and maximum values of tree diameter, height and volume for each plot ( $\mathrm{x}_{\text {mean }}, \mathrm{x}_{\min }, \mathrm{x}_{\max }$ where $x$ is the $d, h$ or tree volume, respectively), Table 2.

The vertical species profile index $\left(\mathrm{A}_{\text {index }}\right)$ according to (Pretzsch, 2009) allows for comparison of vertical structure differentiation between mixed and pure stands. The $\mathrm{A}_{\text {index }}$ quantifies the vertical stand structuring of each tree species within different height zones. Any deviation from a single-layered pure stand is reflected as a distinct increase in the species profile index. $A_{\text {index }}$ can be standardized to a relative vertical species profile index $\left(\mathrm{A}_{\text {rel }}\right)$, facilitating comparisons between stands with differing numbers of species. Detailed explanation is provided in Appendix B.

Gini coefficient for tree volume $\left(\mathrm{GC}_{\mathrm{v}}\right)$ and volume growth $\left(\mathrm{GC}_{\mathrm{iv}}\right)$ were used to quantify inequalities in volume distribution and growth allocation among trees in a stand, respectively (Binkley et al., 2006). We applied the Lorenz curve and the Gini coefficient in order to discover whether mixing modifies the size growth hierarchy among trees in a population. GC $=0.0$ represents a homogeneous distribution and means that all trees are equal in size or growth. Higher GC corresponds to greater size or growth inequality among trees (see Appendix B).

\subsection{Intraspecific differences in tree allometry}

Stand density and competition can considerably modify crown allometry and tree morphology. Species-specific characteristics of crown shape and allometric scaling are relevant for understanding the tree species size development, especially in mixed stands (Pretzsch, 2014). We used $h, h c b$ and $d$ measurements from 938 and 858 stems of $P$. pinaster and $P$. sylvestris, respectively, to develop $h-d$ and $h c b-d$ allometric functions for each species using standardized major axis regression (SMA) in R package 'smatr' (Warton et al., 2012). SMA regression is preferable to ordinary least squares regression when neither variable is clearly the dependent variable and the objective is to estimate how one variable scales against another. Such a line is a summary in the sense that a single dimension is used to describe two-dimensional data (Warton et al., 2006). Allometries were fitted by log-transforming $h-d$ and $h c b$ - $d$ relationships, assuming that above-ground allometry follows a power-law function or allometric relation; $y=\alpha x^{\beta}$. 
Table 2

Mean values and standard error of structural measures for monospecific and mixed-species stands of Scots pine and Maritime pine.

\begin{tabular}{|c|c|c|c|c|c|c|c|c|c|c|}
\hline \multirow[t]{2}{*}{ Structure traits } & \multicolumn{2}{|l|}{$\mathrm{PS}_{\text {pure }}$} & \multicolumn{2}{|l|}{$\mathrm{PT}_{\text {pure }}$} & \multicolumn{2}{|l|}{$\mathrm{PS}_{\mathrm{mix}}$} & \multicolumn{2}{|l|}{$\mathrm{PT}_{\text {mix }}$} & \multicolumn{2}{|l|}{$\operatorname{Mix}_{\mathrm{obs}}$} \\
\hline & mean & SE & mean & SE & mean & SE & mean & SE & mean & SE \\
\hline $\mathrm{d}_{\text {mean }}$ & 30.06 & 1.49 & 32.52 & 1.56 & 28.81 & 1.64 & 37.63 & 2.02 & 32.31 & 1.96 \\
\hline $\mathrm{d}_{\min }$ & 14.58 & 1.18 & 17.46 & 1.68 & 14.88 & 1.97 & 25.78 & 2.38 & 14.54 & 1.71 \\
\hline $\mathrm{d}_{\max }$ & 46.83 & 2.17 & 49.22 & 1.88 & 44.61 & 2.18 & 51.14 & 2.17 & 52.68 & 1.80 \\
\hline $\mathrm{h}_{\text {mean }}$ & 19.89 & 0.80 & 17.59 & 0.78 & 18.94 & 1.04 & 20.48 & 1.18 & 19.55 & 1.04 \\
\hline $\mathrm{h}_{\min }$ & 13.03 & 1.25 & 12.34 & 1.38 & 13.28 & 1.25 & 17.04 & 1.49 & 12.80 & 1.36 \\
\hline $\mathrm{h}_{\max }$ & 24.35 & 1.03 & 21.18 & 0.85 & 23.02 & 1.05 & 23.62 & 1.22 & 24.18 & 1.10 \\
\hline $\mathrm{v}_{\text {mean }}$ & 0.71 & 0.08 & 0.74 & 0.08 & 0.64 & 0.09 & 1.13 & 0.15 & 0.82 & 0.09 \\
\hline $\mathrm{v}_{\min }$ & 0.14 & 0.03 & 0.20 & 0.05 & 0.18 & 0.07 & 0.54 & 0.11 & 0.16 & 0.05 \\
\hline $\mathrm{v}_{\max }$ & 1.72 & 0.18 & 1.72 & 0.17 & 1.45 & 0.17 & 2.05 & 0.23 & 2.16 & 0.22 \\
\hline$A_{\text {rel }}$ & 49.25 & 20.71 & 54.04 & 19.13 & 62.54 & 8.30 & 51.04 & 11.77 & 69.64 & 8.75 \\
\hline $\mathrm{GC}_{\mathrm{v}}$ & 0.27 & 0.02 & 0.26 & 0.02 & 0.27 & 0.02 & 0.22 & 0.02 & 0.30 & 0.02 \\
\hline $\mathrm{GC}_{\mathrm{iv}}$ & 0.29 & 0.02 & 0.28 & 0.02 & 0.29 & 0.02 & 0.24 & 0.02 & 0.36 & 0.02 \\
\hline
\end{tabular}

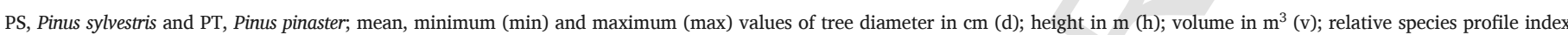
$\left(\mathrm{A}_{\mathrm{rel}}\right)$; Gini coefficient for tree volume $\left(\mathrm{GC}_{\mathrm{v}}\right)$ and volume growth $\left(\mathrm{GC}_{\mathrm{iv}}\right)$.

We treated stand species composition as a factor for each species model (mixture or monospecific stand). Then, we used the likelihood ratio test to ascertain whether the slope of the allometric functions differed according to species mixing (Warton et al., 2006). Thus, we evaluated in what extent the inter- vs. intraspecific environment influence above-ground allometry.

\subsection{Mixing effects on stand structure}

The mean ratio $(R x)$ and its standard error (SE) of tree size distribution traits and inequality growth indices (Gini coefficients) between mixed $\left(x_{\text {mixed }}\right)$ and pure $\left(x_{\text {pure }}\right)$ stands were calculated. These provide a simple basis for testing whether species mixing alters stand structural characteristics compared to monocultures. Mean ratios $\left(R x=x_{\text {mixed }} / x_{\text {pure }}\right)$ significantly different from 1 (1.0 is beyond the confidence intervals) can be considered a mixture effect (see details in Pretzsch and Schütze, 2016). We used the t.test and wilcox.test functions for normally and non-normally distributed ratios, respectively.

Differences in any structural attributes between mixed and pure stands may be due to an additive or a multiplicative effect. Additive effects quantify heterogeneity when both species retain the same structural behavior in mixed stands as in monocultures. They represent how complementary species traits would be in a mixture if their size or shape did not vary from those grown in a monoculture (Pretzsch and Schütze, 2016). The expected additive effect was quantified as the weighted mean of the pure stand characteristics; any deviations in the mixed stand from this weighted mean were considered multiplicative or interactive effects.

We first compared the structural traits between species growing in mixed stands and monocultures. Then, in order to reveal any additive effects we compared the weighted mean of the structural traits of the two monocultures with both monocultures $\left(R x=x_{\text {exp }} / x_{\text {pure }}\right)$. This may indicate how species selection alone can modify mixed stand traits with respect to monocultures. The weighted mean of both monocultures $\left(\hat{D}_{P S, P T}\right)$ represents the expected distribution of each structural trait under the assumption that mixing causes an additive effect. They were calculated by multiplying the monospecific stand distributions ( $D_{P S}$ and $D_{P T}$ ) in such a way that the observed species mixing proportion of the mixed stand was reproduced. This resulted in $\widehat{D}_{P S, P T}=D_{P s}$

- $m_{P S,(P T)}+D_{P T} \cdot m_{(P S), P T}$, where $m_{P S,(P T)}$ and $m_{(P S), P T}$ are the proportions calculated based on the species stand density index, weighted by equivalence coefficients (see Section 2.6).

We used structural traits (Table 2) to test for a multiplicative mixing effect on the Scots pine and Maritime pine mixed stands. At the stand level, this was done by comparing the observed distribution of mixed stands $D_{P S, P T}$ with the weighted mean distribution $\hat{D}_{P S, P T}$. Analogously, the contribution of each species to a multiplicative mixing effect was analyzed, and the structural traits of a species in mixture $\left(D_{P S,(P T)}\right.$, $\left.D_{(P S), P T}\right)$ were compared to those in monoculture $\left(D_{P S}, D_{P T}\right)$. Again, the species distribution of structural traits in mixture had to be scaled up to a unit area of 1 ha using the species mixing proportions (Pretzsch et al., 2016).

\subsection{Evaluation of mixing effects on stand productivity}

Net effects on stand growth is a key question when comparing growth and yield in pure and mixed stands and may result in under-, neutral-, or over-yielding or even transgressive over-yielding (Pretzsch and Schütze, 2009). In addition to whole-stand analysis, we explored species-specific growth in mixture and compared them to the respective monospecific stands, applying the nomenclature and algorithm used by Pretzsch et al. (2015a, 2015b) and del Río et al. (2016). This may improve understanding of stand level reactions.

In order to determine whether mixing affects productivity at the stand level, relative productivity $\left(\mathrm{RP}_{P S, P T}=P_{P S, P T} / \widehat{P}_{P S, P T}\right)$ can be used as the ratio of observed productivity in a mixed stand $\left(P_{P S, P T}=p p_{P S,(P T)}+p p_{(P S), P T}\right)$ divided by the expected productivity for the mixed stand $\left(\widehat{P}_{P S, P T}=P_{P S} \cdot m_{P S,(P T)}+P_{P T} \cdot m_{(P S),(T}\right)$, which is obtained from the productivity of both species in the neighboring pure stands $\left(P_{i}\right)$ and their mixing portions $\left(m_{i}\right)$. The total productivity of the mixed stand is the shared productivity of Scots pine $\left(p p_{P S,(P T)}\right)$ and Maritime pine $\left(p p_{(P S), P T}\right)$. In the same way, relative productivity is used to compare species performance in mixed versus pure stands. For Scots pine, $\mathrm{RP}_{P S,(P T)}=p p_{P S,(P T)} / m_{P S,(P T)} / P_{P S}$; notice that $p p_{P S,(P T)} / m_{P S,(P T)}$, is the contribution of Scots pine in the mixed stand scaled up to 1 ha using the mixing proportion. Relative productivity for Maritime pine $\mathrm{RP}_{(P S), P T}$ was established in the same way.

To measure productivity, we used the mean periodic stand basal area growth (PAIBA, $\mathrm{m}^{2} \mathrm{ha}^{-1}$ year $^{-1}$ ) and mean periodic stand volume growth (PAIV, $\mathrm{m}^{3} \mathrm{ha}^{-1}$ year $^{-1}$ ) for the $2004-2014$ period. If the observed productivity is higher than the reference productivity $\left(P_{P S, P T}>\right.$ $\widehat{P}_{P S, P T}$ ), this indicates a positive mixing effect (over-yielding), whereas the opposite is true (under-yielding) if the observed productivity is lower $\left(P_{P S, P T}<\widehat{P}_{P S, P T}\right)$.

The species-specific growing space occupied is relevant for calculation of the mixing proportions, stand density, and quantification of mixing effects on growth (Sterba et al., 2014). The mixing proportions $(m)$ were based on stand density index (SDI) (Reineke, 1933) weighted by equivalence coefficients, in order to compare species-specific growing space requirements of a species with their value in mixed stands 
(del Río et al., 2016; Pretzsch and Biber, 2016; Sterba et al., 2014). Maximum stand density for each species (SDImax) were calculated based on specific functions of SDImax (del Río et al., 2001; Riofrío et al., 2017b). Equivalence coefficient using Scots pine as reference species was determined as $1.03\left(\mathrm{e}_{\mathrm{PT} \Rightarrow \mathrm{PS}}=\operatorname{SDImax}_{P S} /\right.$ SDImax $\left._{P T}\right)$.

The resulting SDI's transformed by the equivalence coefficients value were used to calculate density in mixed stands $\left(\mathrm{SDI}_{P S, P T}=\mathrm{SDI}_{P S,(P T)}+\mathrm{SDI}_{(P S), P T} \cdot \mathrm{e}_{\mathrm{PT} \Rightarrow \mathrm{PS}}\right)$ and the relative density $\left(\mathrm{RD}_{P S, P T}=\mathrm{SDI}_{P S, P T} / \mathrm{SDI}_{P S}\right)$, which measures over/understocking in the mixed-species stands in relation to neighboring monocultures within each triplet (Pretzsch and Biber, 2016). Thus, species mixing proportions might be calculated to avoid bias in the quantification of the net total mixing effect, as well as in the relative importance of under- or over-yielding by species, due to differences in the potential densities of the species. The mixing proportions for both species are:

$\mathrm{m}_{\mathrm{PS},(\mathrm{PT})}=\mathrm{SDI}_{\mathrm{PS},(\mathrm{PT})} /\left(\mathrm{SDI}_{\mathrm{PS},(\mathrm{PT})}+\mathrm{SDI}_{(\mathrm{PS}), \mathrm{PT}} \cdot \mathrm{e}_{\mathrm{PT} \Rightarrow \mathrm{PS}}\right)$

$\mathrm{m}_{(\mathrm{PS}), \mathrm{PT}}=\left(\mathrm{SDI}_{(\mathrm{PS}), \mathrm{PT}} \cdot \mathrm{e}_{1}\right) /\left(\mathrm{SDI}_{\mathrm{PS},(\mathrm{PT})}+\mathrm{SDI}_{(\mathrm{PS}), \mathrm{PT}} \cdot \mathrm{e}_{\mathrm{PT} \Rightarrow \mathrm{PS}}\right)$

\subsection{Relationships between mixing effects at different levels of organization}

Finally, we used OLS linear regression to attempt to explain the relationship between the mixing effect on relative productivity at the stand level $\left(\mathrm{RP}_{P S, P T}\right)$ and species level $\left(\mathrm{RP}_{P S,(P T)}\right.$ and $\left.\mathrm{RP}_{(P S), P T}\right)$ with variability in stand attributes and stand structural trait ratios in mixed versus pure stands. Statistical analysis of the relationships between canopy characteristics and relative productivity between mixed and pure stands may reveal the relevance of observed contrasts between species tree crowns and canopy structures in terms of productivity gains or losses (Pretzsch, 2014).

\section{Results}

\subsection{Mixing-related changes in tree allometry}

Height-diameter relationships varied significantly between stand compositions in both species (Fig. 1 and Table S3). The $h c b-d$ allometry relationship, in contrast, remained constant for Maritime pine but dif-

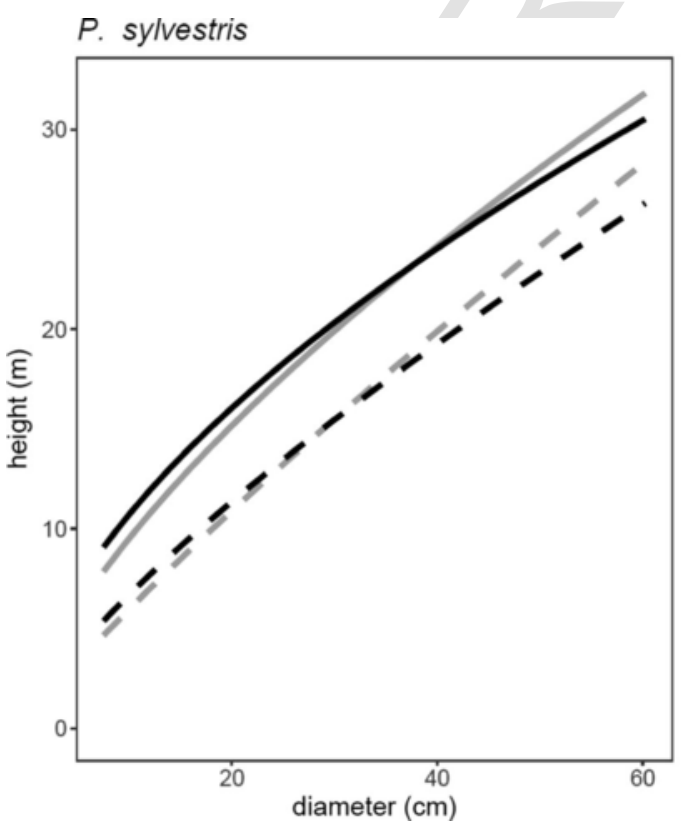

fered for Scots pine trees growing in mixture versus monocultures. Parameters and statistical tests of the fitted functions are shown in Table S1. Maritime pine trees growing in mixture tended to be significantly higher in mixture, presented a considerably steeper slope in the $h$ - $d$ relationship and had longer crowns as size increased. Despite the slope differences in both functions for Scots pine, vertical crown extension was similar in mixture than in monospecific stands. This pattern concurs with intra-specific stand structural traits ratios (Tables 3 and S2).

\subsection{Comparing structural attributes between species and composition}

Inter-specific comparison of stand characteristics between pure and mixed stands (Fig. 2) showed that quadratic mean diameter was significantly greater for Maritime pine than for Scots pine in mixed stands, whereas the mean dq ratio between species in pure stands did not differ from 1. The opposite pattern was observed for dominant height: pure Scots pine stands were on average about 19\% taller than pure Maritime pine stands, while in mixed stands both species reached similar dominant height. However, these mean relationships varied due to differences in site conditions and age prevailing on the triplets. These differences show an overview of the stands characteristics and reveal which role each species plays in the mixture as an indication of their competitive status. SDI was about $24 \%$ higher in pure Maritime pine than in pure Scots pine stands (Fig. S2). Despite the lower dominant height of pure Maritime pine, the higher SDI and dq resulted in $20 \%$ and $8 \%$ higher basal area and standing volume compared to pure Scots pine stands. Greater differences of $37 \%$ and $43 \%$ were observed for PAIBA and PAIV, respectively.

In mixed stands, the quadratic mean diameter of Maritime pine was $16 \%$ higher and dominant height was $18 \%$ higher than in pure stands (Table 3). For Scots pine, quadratic mean diameter and dominant height were $3 \%$ and $4 \%$ lower in mixed stands, respectively, but the differences were not significant. SDI in mixed stands increased for Scots pine but maintained similar for Maritime pine compared to pure stands. Although the stands represent fully stocked and almost unthinned conditions, SDI values varied considerably among triplets due to the wide range in site conditions and the variation in stand age.

The structural attribute ratios for mixed versus monoculture stands $\left(\mathrm{Mix}_{\mathrm{obs}} /\right.$ Pure) are presented in Table 4 . The maximum diameter and

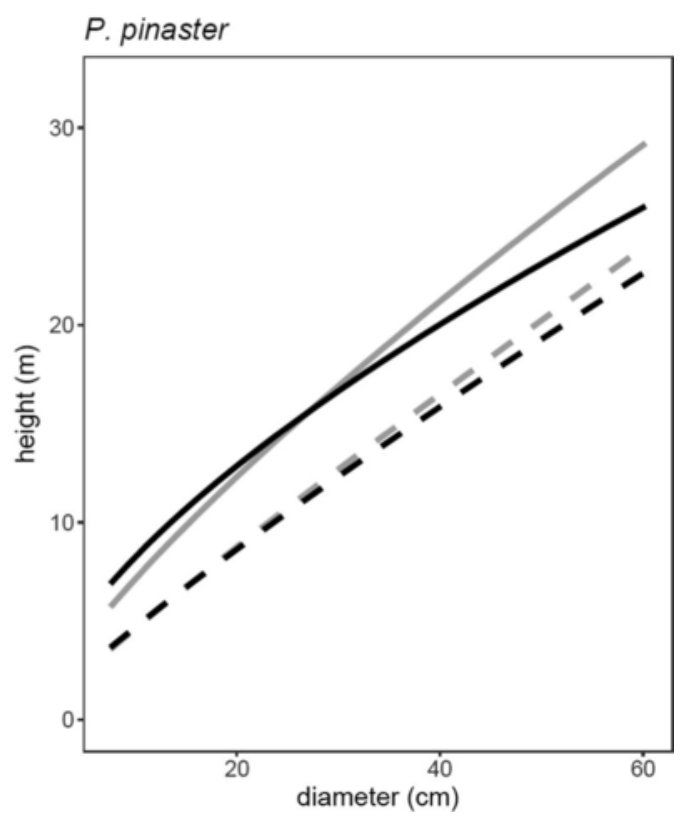

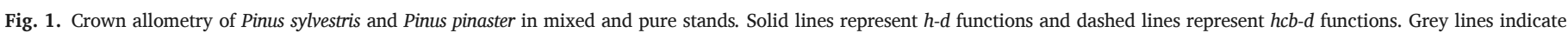
trees in mixture, black lines indicate trees growing in monocultures. 
Table 3

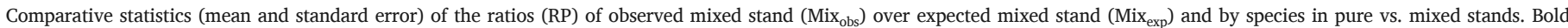
values indicate significant differences in ratios, $p \leq 0.05$.

\begin{tabular}{|c|c|c|c|c|c|c|}
\hline & \multicolumn{2}{|c|}{$\mathrm{Mix}_{\mathrm{obs}} / \mathrm{Mix}_{\mathrm{exp}}$} & \multicolumn{2}{|c|}{$\mathrm{PS}_{\text {mix }} / \mathrm{PS}_{\text {pure }}$} & \multicolumn{2}{|c|}{$\mathrm{PT}_{\text {mix }} / \mathrm{PT}_{\text {pure }}$} \\
\hline & mean & SE & Mean & SE & Mean & SE \\
\hline $\mathrm{N}\left(\right.$ trees ha $\left.{ }^{-1}\right)$ & 0.96 & 0.05 & $1.35^{* *}$ & 0.14 & $0.72^{* * *}$ & 0.03 \\
\hline $\mathrm{dq}(\mathrm{cm})$ & & & 0.97 & 0.04 & $1.16^{\text {\#\#* }}$ & 0.03 \\
\hline hq (m) & & & 1.02 & 0.06 & $1.18^{\text {****}}$ & 0.04 \\
\hline ho (m) & & & 0.96 & 0.03 & $1.15^{\text {****}}$ & 0.03 \\
\hline $\mathrm{hq} / \mathrm{dq}$ & & & 1.04 & 0.05 & 1.03 & 0.04 \\
\hline $\mathrm{BA}\left(\mathrm{m}^{2} \mathrm{ha}^{-1}\right)$ & 1.05 & 0.04 & 1.20 & $0.05^{* \hbar * \hbar}$ & 0.97 & 0.05 \\
\hline $\mathrm{V}\left(\mathrm{m}^{3} \mathrm{ha}^{-1}\right)$ & $1.12^{*}$ & 0.05 & 1.16 & $0.07^{* \hbar}$ & $1.11^{\text {\#** }}$ & 0.07 \\
\hline SDI & 1.06 & 0.04 & 1.21 & $0.05^{* \ldots *}$ & 0.96 & 0.05 \\
\hline PAIBA $\left(\mathrm{m}^{2} \mathrm{ha}^{-1} \mathrm{yr}^{-1}\right)$ & 1.08 & 0.07 & 1.06 & 0.08 & 1.09 & 0.08 \\
\hline PAIV $\left(\mathrm{m}^{3} \mathrm{ha}^{-1} \mathrm{yr}^{-1}\right)$ & $1.14^{*}$ & 0.07 & 1.11 & 0.11 & $1.19^{*}$ & 0.08 \\
\hline
\end{tabular}

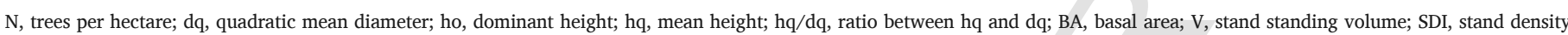

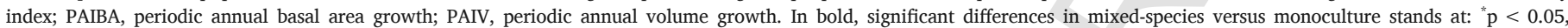
${ }^{* *} \mathrm{p}<0.01$ and ${ }^{* * * *} \mathrm{p}<0.001$.

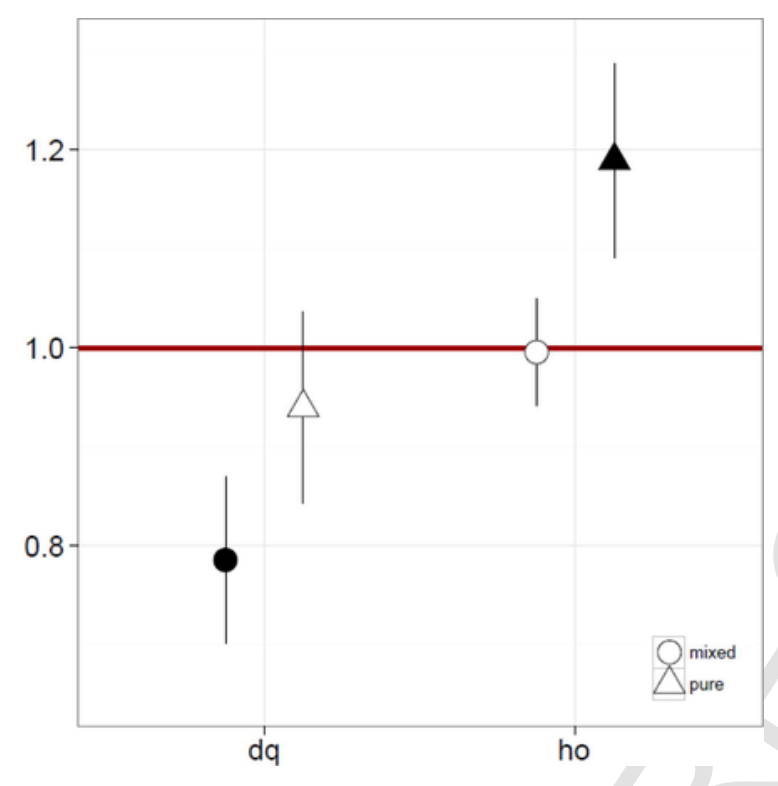

Fig. 2. Inter-specific ratio of quadratic mean diameter and dominant height between mixed or pure stands ( $\mathrm{PS}_{\text {mix }} / \mathrm{PT}_{\text {mix }}$ and $\mathrm{PS}_{\text {pure }} / \mathrm{PT}_{\text {pure }}$ ). Filled symbols indicate mean ratio significantly different from one $(\mathrm{p}<0.05)$.

volume values indicated a significantly wider size distribution in mixed-species stands compared to both monocultures. We detected more heterogeneity of vertical structure $\left(A_{\text {rel }}\right)$ in mixed stands com- pared to monospecific stands. The $\mathrm{GC}_{\mathrm{v}}$ for mixed stands did not significantly differ from the monocultures. The Gini-coefficient for stem volume growth $\left(G_{i v}\right)$ indicated greater growth allocation inequality in favor of tall trees in mixed stands, compared to the rather homogeneous monocultures, and this difference was stronger when comparing with Maritime pine than with Scots pine: $\mathrm{RG}_{\mathrm{iv}}=1.31$ and 1.25 , respectively.

Inter-specific trait differences for species growing in mixture or monocultures (Fig. 3) showed some shifts in traits ratios emerged when we compared species-specific traits in mixed stands $\left(\mathrm{PS}_{\text {mix }} \mathrm{vs} . \mathrm{PT}_{\text {mix }}\right.$ ) with pure stands ( $\mathrm{PS}_{\text {pure }}$ Vs. $\mathrm{PT}_{\text {pure }}$ ). Size distribution values of mean diameter, height and volume, as well as minimum diameter and volume, were higher for Maritime pine than Scots pine in mixture. Significant differences were also observed in vertical structure and growth inequality indexes, and were greater for Scots pine in mixture, which corroborated the differences observed in dominant height at stand level between monocultures (Fig. 2).

\subsection{Additive and multiplicative effects of species mixing on structural traits}

The additive effects ( $\mathrm{Mix}_{\exp }$ vs. Pure) on structural traits (Table 4) showed a weak additive effect of mixture compared to Scots pine pure stands and a moderate effect compared to Maritime pine: species structural indices differed between weighted stands and monocultures for 4 out of 12 in the former and 6 out of 12 in the latter. Scots pine monoculture compared with the expected mixed stand (weighted mean of both monocultures) showed higher diameter and volume maximum

Table 4

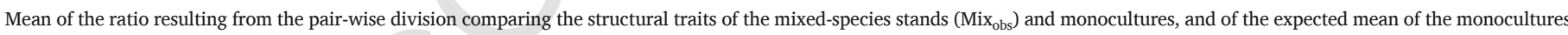
( Mix $_{\text {exp }}$, weighted mean pure stands by mixing proportions) with the neighboring monocultures.

\begin{tabular}{|c|c|c|c|c|c|c|c|c|}
\hline \multirow[t]{2}{*}{ Structure traits } & \multicolumn{2}{|c|}{ Mix $_{\text {obs }}$ vs. PS pure } & \multicolumn{2}{|c|}{$\mathrm{Mix}_{\mathrm{obs}}$ vs. $\mathrm{PT}_{\text {pure }}$} & \multicolumn{2}{|c|}{$\mathrm{Mix}_{\exp }$ vs. PS $\mathrm{S}_{\text {pure }}$} & \multicolumn{2}{|c|}{$\mathrm{Mix}_{\exp }$ vs. $\mathrm{PT}_{\text {pure }}$} \\
\hline & mean & SE & mean & SE & Mean & SE & mean & SE \\
\hline $\mathrm{d}_{\text {mean }}$ & 1.08 & 0.04 & 0.99 & 0.03 & 1.03 & 0.03 & 0.96 & 0.02 \\
\hline $\mathrm{d}_{\min }$ & 1.04 & 0.11 & 0.87 & 0.09 & 0.92 & 0.05 & $0.79^{* * * * *}$ & 0.05 \\
\hline$d_{\max }$ & $1.14^{* *}$ & 0.05 & $1.08^{*}$ & 0.03 & $1.12^{* *}$ & 0.03 & 1.07 & \\
\hline $\mathrm{h}_{\text {mean }}$ & 0.98 & 0.04 & $1.11^{* * *}$ & 0.03 & $0.94^{*}$ & 0.03 & $1.06^{* *}$ & 0.02 \\
\hline $\mathrm{h}_{\min }$ & 1.08 & 0.14 & 1.12 & 0.10 & $0.65^{*}$ & 0.05 & $0.89^{*}$ & 0.06 \\
\hline $\mathrm{h}_{\max }$ & 0.99 & 0.14 & $1.15^{* *}$ & 0.04 & 1.01 & 0.01 & $1.17^{* *}$ & 0.05 \\
\hline $\mathrm{v}_{\text {mean }}$ & 1.21 & 0.10 & 1.14 & 008 & 1.04 & 0.06 & 0.98 & 0.05 \\
\hline $\mathrm{v}_{\min }$ & 1.26 & 0.50 & 1.15 & 0.33 & 0.85 & 0.10 & $0.60^{* *}$ & 0.09 \\
\hline $\mathrm{v}_{\max }$ & $1.35^{* *}$ & 0.12 & $1.28^{* * *}$ & 0.09 & $1.25^{* *}$ & 0.08 & 1.59 & \\
\hline $\mathrm{A}_{\text {rel }}$ & $1.42^{* *}$ & 0.66 & $1.24^{* * *}$ & 0.10 & 1.15 & 0.68 & 1.02 & 0.42 \\
\hline $\mathrm{GC}_{\mathrm{v}}$ & 1.15 & 0.09 & 1.23 & 0.10 & 1.07 & 0.06 & $1.14^{*}$ & 0.05 \\
\hline $\mathrm{GC}_{\mathrm{iv}}$ & $1.25^{* *}$ & 0.08 & $1.31^{* * *}$ & 0.10 & 1.08 & 0.04 & 1.12 & 0.06 \\
\hline
\end{tabular}

PS, Pinus sylvestris and PT, Pinus pinaster. In bold, significant differences in mixed-species stand versus monoculture at: ${ }^{*} \mathrm{p}<0.05$, ${ }^{* * *} \mathrm{p}<0.01$ and ${ }^{* * * *} \mathrm{p}<0.001$. 


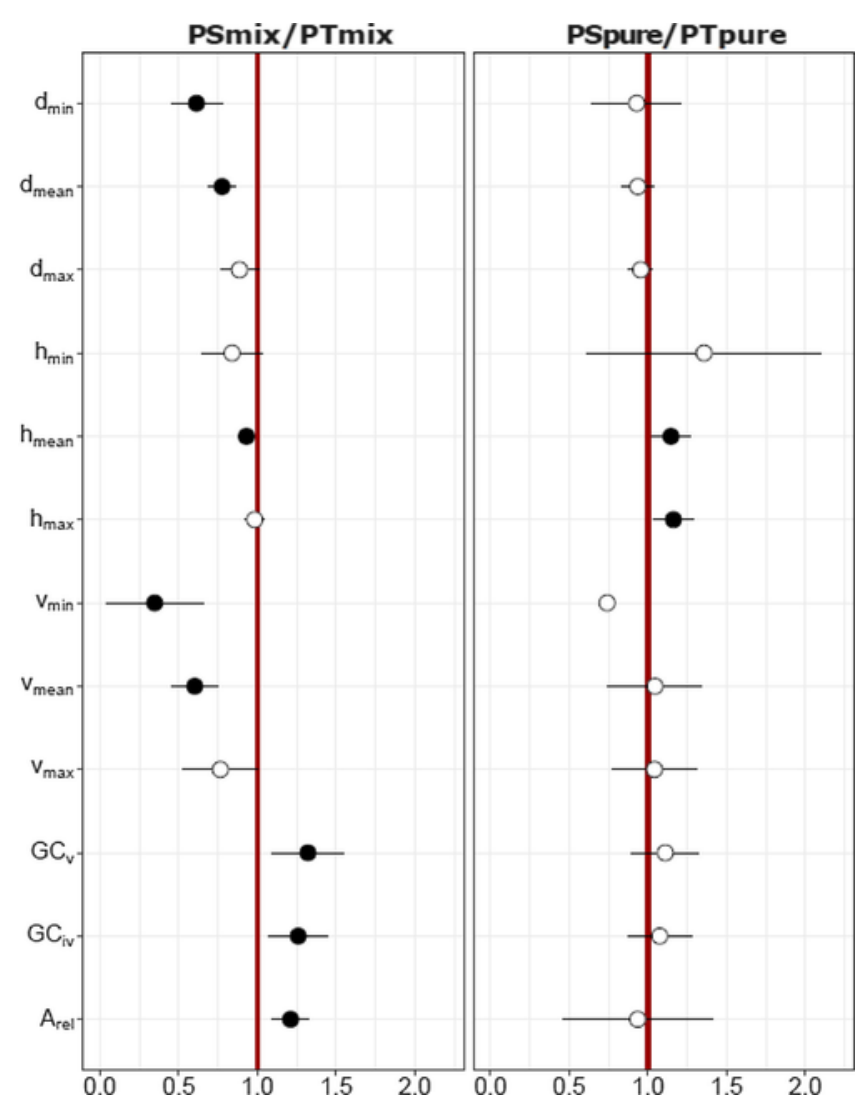

Fig. 3. Mean of the ratio resulting from the pair-wise division of the structural traits between species growing in mixed stands and monocultures. PS: Pinus sylvestris and PT: Pinus pinaster. Filled circles indicate mean ratio significantly different from one $(\mathrm{p}<0.05)$.

values. However, mean and minimum heights were reduced by the component of Maritime pine in the expected mixed stand.

Maritime pine monoculture showed significantly higher mean and maximum height values compared to the weighted mean of both monocultures, and lower minimum diameter, height and volume values than expected in mixed stands. These indicate that a broader size distribution range was expected in mixed stands than in monospecific stands, especially with regard to tree height size distribution. The higher $\mathrm{GC}_{\mathrm{v}}$ means greater inequality in the standing stand volume for the weighted mean of the two monocultures than in the Maritime pine monoculture. All these comparative differences in structural traits for both species imply that structural heterogeneity may increase just by mixing.

The multiplicative mixing effects obtained by comparing the structural traits between species in mixed and pure stands are shown in Fig. 4. Differences between observed mixed-stand structural indexes and the weighted mean of both monocultures ( $\mathrm{Mix}_{\mathrm{obs}}$ vs. $\mathrm{Mix}_{\mathrm{exp}}$ ) are also shown. No shifts in structural traits for Scots pine were observed in mixtures compared to monocultures, $\mathrm{PS}_{\mathrm{mix}} / \mathrm{PS}_{\text {pure }}$ (Fig. 4). In contrast, most of the size distribution traits were significantly higher for Maritime pine in mixed-species stands. Only $\mathrm{GC}_{\mathrm{V}}$ was lower compared to Maritime pine monocultures $\left(\mathrm{PT}_{\text {mix }} / \mathrm{PT}_{\text {pure }}\right.$ ). We might consider these changes in the structural indexes of Maritime pine growing in mixture versus monoculture to be closely related to shifts in structural traits patterns when species coexist in mixing ( $\mathrm{PS}_{\text {mix }} / \mathrm{PT}_{\text {mix }}$ ) or to comparison of species in pure stands $\left(\mathrm{PS}_{\text {pure }} / \mathrm{PT}_{\text {pure }}\right)$. However, the multiplicative effect of species mixing at the stand level $\left(\mathrm{Mix}_{\mathrm{obs}}\right.$ vs. $\left.\mathrm{Mix}_{\mathrm{exp}}\right)$ does not always emerge from patterns at the species level.

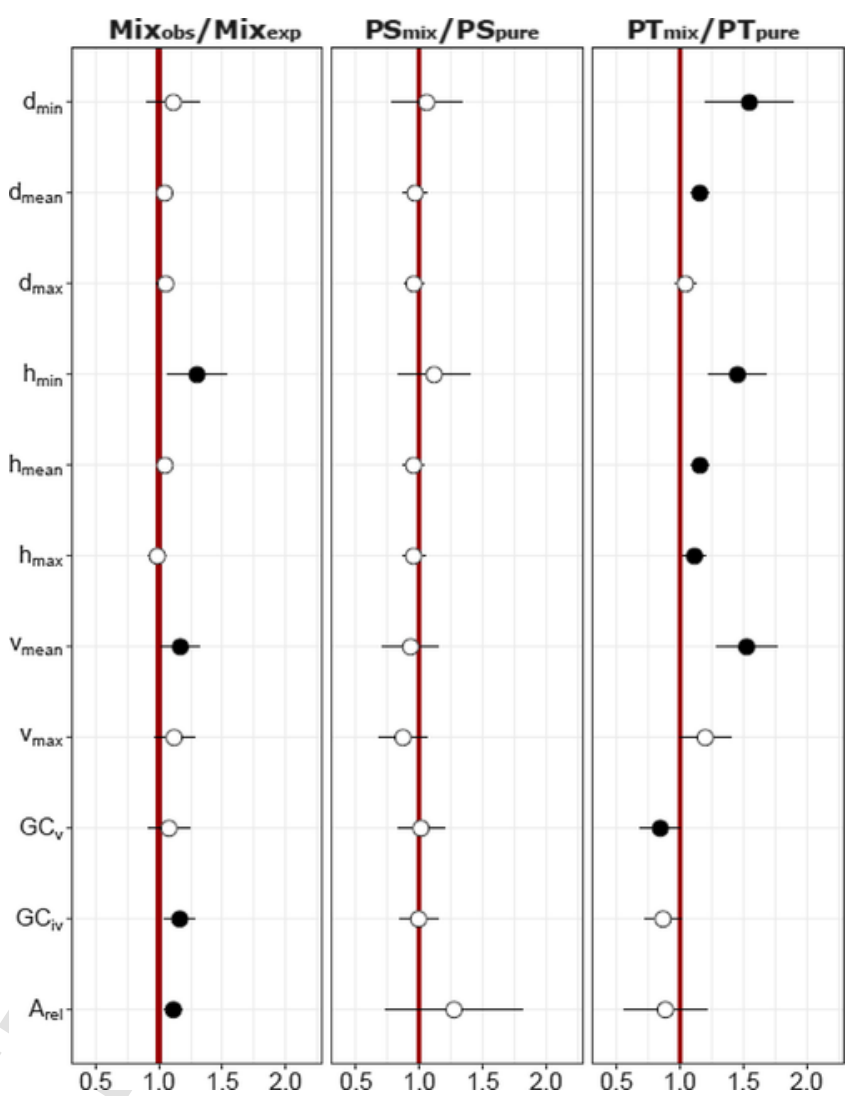

Fig. 4. Multiplicative mixing effects on the structural traits of Scots pine and Maritime pine in mixed stands compared with monocultures. Circles are the mean of the ratio resulting from the pair-wise division of the structural traits of the mixed-species stands by the respective value of the neighboring monocultures. Filled circles indicate mean ratio significantly different from one $(\mathrm{p}<0.05)$.

\subsection{Over- and under-yielding and structural heterogeneity relationships}

Table 3 shows that standing volume and PAIV values were an average of $12 \%$ and $14 \%$ higher in mixed stands than in pure stands, respectively. However, BA, PAIBA and SDI were similar in mixed and pure stands. Higher volume was caused by the higher volume (RP $\mathrm{V}_{(P S) P T}=1.11$ ) and mean annual volume growth (RP PAIV $\left.{ }_{(P S) P T}=1.19\right)$ of Maritime pine in mixed stands, compared to pure stands. Though PAIBA was higher for Maritime pine in mixed stands (1.09), the effect was not significant at the total mixed-stand level.

The variability of relative stand productivity at the stand and species levels was related to certain stand characteristics and the intra-specific ratio of structural traits between mixed and pure stands $\left(x_{\text {mixed }} / x_{\text {pure }}\right)$. We focused on whole stand $\left(\mathrm{RP}_{P S, P T}\right)$ and Maritime pine relative productivity in mixed stands $\left(\mathrm{RP}_{(P S), P T}\right)$ since both showed significant effects of mixture on the PAIV (Table 3, Fig. S3). Accordingly, we explored the significant ratios of the structural traits between Maritime pine in mixed-species stands and monocultures ( $\mathrm{PT}_{\text {mix }}$ vs. $\mathrm{PT}_{\text {pure }}$ ) as explanatory variables (Fig. 3). In both cases, we accounted for relative stand density $\left(\mathrm{RD}_{P S, P T}\right.$ ), site index (dominant height of Maritime pine at age 100 in mixed stand) and age (age of Maritime pine in mixed stand).

Relative stand productivity increased significantly with relative stand density, $\mathrm{RD}_{P S, P T}$ (Figs. S4 and S5). However, site index and age had non-significant effects on RP, though they presented a slightly positive correlation. Both the over-yielding observed at stand level and species level for Maritime pine were related to structural ratios describing tree height differences for Maritime pine in mixed-species stands 
and monocultures. $\mathrm{RP}_{P S, P T}$ and $\mathrm{RP}_{(P S), P T}$ increased as the difference in maximum tree height of Maritime pine trees in mixed stands increased with respect to monocultures $\left(\mathrm{Rh}_{\max }\right)$ (Table 5).

\section{Discussion}

We found evidence of increased structural heterogeneity and productivity in mixed-pine stands when compared to monocultures. Our results showed that part of the variation in the relative productivity of mixed stands can be explained by changes in size structure through species mixing. Analyzing size-structure dynamics in mixed stands can therefore link findings at individual tree and stand levels (Pretzsch and Schütze, 2016). Thus, this study helped trace the effects of species mixing and formulate hypothesis of possible mechanisms behind the positive diversity-productivity relationship, based on empirical evidence at species level, size-structure and stand level.

\subsection{Crown allometry plasticity by species mixing}

We found that tree crown morphology was significantly influenced by interspecific versus intraspecific competition, which is consistent with studies showing that interspecific interactions affect species-specific allometric relationships (Forrester et al., 2017a; Pretzsch, 2014). Vertical crown extension of Maritime pine was greater in mixed versus pure stands, especially in larger trees (Fig. 1). This may signify niche partitioning processes resulting from the slow, continual feedback between structure, environment, and tree growth in mixed stands (Pretzsch, 2014). Crown plasticity, or the ability of trees to develop complementary crown morphologies in response to changes in their local competitive environment, is a critical element that promotes efficient canopy packing and reduces the intensity of light competition in mixed forests (Ishii and Asano, 2010; Jucker et al., 2015).

Despite the variability of allometric relationships explained by the inclusion of stand composition in the model (Table S3), the differences of species height and crown allometry comparing trees growing in monoculture versus mixture could not be attributed only to interspecific interactions. Differences of density and canopy structures across plots, which in part can be due to interspecific interactions, might modify crown allometry and tree morphology. Inclusion of stand structural variables in allometric equations can help to account for variability in stand densities (Forrester et al., 2017b). In addition, Vizcaíno-Palomar et al., (2016) observed that both Maritime pine and Scots pine have shown inter-population tree height allometry variation as result of adaptive responses to either local environments (climate and geographical sites of origin) or to their past genetic background. This emphasizes how allometric relationships in trees are not a static trait for any species (Forrester et al., 2017b), and underscores the need to develop individual tree based growth models for mixed stands considering such species-specific morphological characteristics and other factors affecting these allometric relationships (Pretzsch et al., 2015b).

Table 5

Linear model of the relative productivity in mixed-species versus monocultures at the stand and species levels as function of changes in structural attributes.

\begin{tabular}{lll}
\hline & $\mathrm{RP}_{\mathrm{PS}, \mathrm{PT}}$ & $\mathrm{RP}_{(\mathrm{PS}) \mathrm{PT}}$ \\
\hline Intercept & $-0.178(0.26)$ & $-0.887(0.53)$ \\
$\mathrm{Rh}_{\text {max }}\left(\mathrm{PT}_{\text {mix }} / \mathrm{PT}_{\text {pure }}\right)$ & $1.126(0.2)$ & $1.924(0.47)$ \\
$\mathrm{R}^{2}$ adjusted & 0.710 & 0.669 \\
$\mathrm{RSE}$ & 0.078 & 0.159 \\
$\mathrm{p}$-value & 0.001 & 0.003 \\
\hline
\end{tabular}

$\mathrm{RP}_{P S, P T}$, Relative productivity of mixed-species stands versus monocultures; $\mathrm{RP}_{(P S), P T}$, Relative productivity of Maritime pine mixed-species stands versus monocultures; $\mathrm{Rh}_{\max }$ $\left(\mathrm{PT}_{\text {mix }} / \mathrm{PT}_{\text {pure }}\right)$, ratio between the maximum tree height of Maritime pine in mixed versus monospecific stands. (Standard error).

\subsection{Changes in structural heterogeneity through species mixing}

Stand structure and species diversity are crucial drivers that affect most forest functions and services (Gadow et al., 2012; Pretzsch, 2014). Detailed information on stand structures and size-distribution are required for up-scaling the mixing effects from the individual tree level to the species or stand level and thus improve our understanding and modelling of mixed-species stand dynamics (Forrester and Pretzsch, 2015; Pretzsch, 2014).

The differences in morphological traits between the two species in monospecific stands indicate that Scots pine trees are taller than Maritime pine (Fig. 2: $\mathrm{PS}_{\text {pure }} / \mathrm{PT}_{\text {pure }}$ ). For some structural traits (Table 4: $\mathrm{Mix}_{\exp } /$ Pure), differences between the two species (monoculture compared to the weighted mean of both monocultures) were enough to increase structural heterogeneity just through species mixing: resulting in an additive effect. This implies that these species can show complementary traits in vertical stand structure related to crown architecture and differences in abilities to grow in low light conditions (Gaudio et al., 2011; Sánchez-Gómez et al., 2006). However, the differences between species morphology and stand structure in monocultures provided insufficient information for predicting crown vertical extension, crown packing or structural heterogeneity resulting from emerging mixing effects.

Multiplicative - or true - mixing effects revealed new structural and morphological aspects resulting from inter-specific species-environment interaction (Forrester, 2014; Pretzsch, 2014). At the stand level, vertical stratification and volume growth inequality emerged as the most meaningful multiplicative effects of species interaction in mixed stands (Fig. 3: $\mathrm{Mix}_{\mathrm{obs}} / \mathrm{Mix}_{\mathrm{exp}}$ ). However, most of the mixed-species size-distribution ratios that differed significantly from monocultures at this level showed opposite species reaction traits which counteracted each other and overrode the mixing effects at the whole stand level. Counterbalancing effects at the species level has been reported in mixtures of species with more contrasting morphological traits (Pretzsch et al., 2016).

Enhanced vertical layering through species mixing could be traced mainly due to structural trait shifts in Maritime pine growing in mixture versus monocultures, which contrasted with the steady structural performance of Scots pine. Vertical heterogeneity (Fig. 3), differences in allometric equations (Fig. 1) and the mixing effects on mean tree sizes (Table 3), resulted in stand structures where Maritime pine trend to occupy the dominant canopy layer and larger size-distribution class in mixtures, compared to the inter-specific size-distribution relationship in monocultures. This is consistent with size-dominance of Maritime pine over Scots pine in mixed stands observed by Riofrío et al., (2017b) using inventory data, where Maritime pine tree growth was more strongly influenced by the competition structure (size-symmetric and size- asymmetric) than by the specific composition of the competition (intraspecific and interspecific), indicating that growth is more dependent on size than on species of competitors. Despite dominant height increment is low related to competition effects, interspecific competition for light in mixed forests can modify tree height growth, mean height or dominant height (Amoroso and Turnblom, 2006; Menalled et al., 1998; Pretzsch et al., 2015a). However, the magnitude of the mixture effect on dominant height depending on the species and the associations (Vallet and Perot, 2016) as well as stand density (Amoroso and Turnblom, 2006).

Complementarity or reduced competition due to the space released by Scots pine for above-ground niche occupation or light interception, which is probably enabled by the slight differences in light-use strategies between both species, could considered as a combined effect of interspecific interactions, which has implications for crown architecture in species subjected to heavy competition for light (Ishii and Asano, 
2010; Jucker et al., 2015). Jucker et al., (2014) reported that shifts in size distribution and crown structure in mixed versus pure stands acted as mechanisms for inducing the positive effects of species mixing by enhancing light use efficiency in $P$. sylvestris and $P$. nigra mixtures.

\subsection{Ecological explanation of the mixing effects on productivity and structure}

We observed increased relative volume productivity in mixed stands compared with monocultures (Table 5 and Fig. S2), derived from the significant over-yielding of Maritime pine, whereas the relative productivity of Scots pine remained steady and was unaffected by mixing. These results partially agreed with Riofrío et al., (2017b), where species mixing at the stand level increased productivity and large-scale mutual benefits were observed for both species. This might be due to differences in environmental conditions between the two studies, that may cause spatial variations in over-yielding or mixing effects (Forrester, 2014; Toïgo et al., 2015).

Despite the mean over-yielding, the variability observed in relative productivity among triplets (Fig. S3) highlights the complexity of the several different processes that influence the net complementarity effects between species. Mixing effects depend on stand development stage, stand density, and site conditions (Forrester, 2014), showing in some cases opposite patterns between the same mixed species (Amoroso and Turnblom, 2006; del Río et al., 2014; Pretzsch et al., 2010; Toïgo et al., 2015). In addition, both species have acquired specific sensitivity to drought in different Mediterranean environments (Lara et al., 2013), which may alter species interactions and complementarity relationships over time (del Río et al., 2014; Pretzsch et al., 2013). Also it is relevant to note that, even though the stands had not been managed for about 10 years. Some of the crown architectural and stand structural traits observed in mixed stands might represent the silviculture interference more than the species-specific ability to appropriate resources or adapt to competition. However, the uncertainty in mixing effect observed caused by the past management could not be quantified here.

Some degree of niche partitioning is required for coexisting species, and is reflected in crown characteristics, leaf vertical profiles, shade tolerance, or differences in growth phenology (Forrester, 2014; Jucker et al., 2015; Toïgo et al., 2017). Nonetheless small differences in species structural traits can trigger positive interspecific effects through complementarity or competition reduction mechanisms (Jucker et al., 2014; Riofrío et al., 2017b). In this work, we found that over-yielding at the stand level was related to vertical structural heterogeneity (Table 5) resulting from species interaction, which increased mixed-species stand productivity more than in monocultures. In other words, crown complementarity in canopy space can be thought of as a complementary mechanism that links biodiversity with ecosystem productivity (Forrester et al., 2017a). Similar relationships have been observed in recent studies (Dănescu et al., 2016; Pretzsch and Schütze, 2016; Vallet and Perot, 2016; Williams et al., 2017).

This has notable effects in light-demanding species such as pines, which tend to exhibit suppressed growth due to light competition in monocultures (Gómez-Aparicio et al., 2011). The processes involved in the positive relationship between crown complementarity and over-yielding in mixed stands have been associated with maximized light capture and/or light-use efficiency (Forrester et al., 2017a; Williams et al., 2017). Both process are closely related to crown size characteristics (Binkley et al., 2013); for example, crown projection area has been used to measure species growing-space occupancy and study growing-space efficiency as a proxy for light interception in mixed stands (Dirnberger et al., 2017; Mainwaring and Maguire, 2004; Pretzsch and Schütze, 2009). Following this approach with the same Scots

pine-Mar- itime pine triplets dataset used in the present work, Cattaneo et al., (2017) found that $P$. pinaster increased its growth efficiency at the tree level by growing in mixture with $P$. sylvestris, which showed no benefits from growing in mixture and agreed with the stand-level results mentioned above. Thus, relationships between crown characteristics and tree growth or canopy characteristics and stand growth in mixed stands reveal that, in these trees, crown allometric plasticity and vertical stratification in the canopy can vary in response to local competitive environmental conditions. This is highly relevant in terms of gains or losses in productivity.

Species-specific physiological and morphological plasticity responses to shade conditions allow light-demanding species to coexist (Gratani, 2014; Valladares et al., 2002). In experimental trials with seedlings, Scots pine was able to grow in low light conditions (Gaudio et al., 2011) due to increased total carotenoid concentration and higher ratios of chlorophyll in response to shade than Maritime pine (Sánchez-Gómez et al., 2006). Although the two studied species are rather similar in many traits, the combination of higher crown plasticity in Maritime pine (Vizcaíno-Palomar et al., 2016), slight differences in shade tolerance between species (Poorter et al., 2012), and the higher physiological plasticity of Scots pine (Gaudio et al., 2011; Sánchez-Gómez et al., 2006) allow both species to develop a multi-layered vertical structure and complementary crown architectures when mixed. Thus, intercepted light can also be used more efficiently, suggesting that light-related interactions may contribute to the mixing effect on stand productivity.

Mixed stands may also benefit from temporal complementarity of resource use between species (Cocozza et al., 2016; Eilmann et al., 2011; Swidrak et al., 2013). Riofrío et al. (2017a) reported evidence of accentuated asynchrony in intra-annual growth patterns of Scots pine and Maritime pine in mixed stands, which implies greater temporal niche complementarity than would be expected, based on the behavior of these species in monospecific stands. This asynchrony in intra-annual growth patterns may be also linked to over-yielding (del Río et al., 2017), suggesting that complementarity for other resources such as water may be also contributing to over-yielding.

\section{Conclusion}

Species mixing increases many aspects of structural heterogeneity, leading to greater productivity and over-yielding compared with monocultures. Results presented in this work, corroborate the findings from other studies (Pretzsch and Schütze, 2016; Williams et al., 2017), and highlight the relevance of analyzing size distribution and canopy structure to improve understanding of how emerging properties that result from species mixing affect productivity. Our findings suggest that even small differences in species structural traits that facilitate a crown complementarity environment trigger positive interspecific effects through complementarity or competition reduction. We observed that mixture effect increased as the difference in expected heights increased.

The additive effect showed that mixed stands of Scots pine and Maritime pine can generate richer stand structure by species mixing alone, thanks to differences in ecological traits and structural morphology. However, additive effects do not reproduce the structural heterogeneity observed in mixed stands that emerge mixing effects. This points the need for sound knowledge and reliable models that account for species interactions in simulating mixed-species dynamics.

These findings reinforce the idea that the ability to develop a crown complementarity environment, attributable to both intraspecific and interspecific differences in crown size plasticity and size-distribution differentiation, is a crucial mechanism for enhancing productivity in ecosystems with light-demanding species. 
However, additional analyses are needed to assess the strength and stability of the mechanism that links biodiversity with ecosystem productivity. These mechanisms could be simultaneously affected by stand development stage, environmental conditions, silvicultural history, and sensitivity to other limiting factors that may incorporate spatial and temporal variability.

\section{Acknowledgements}

This study was funded by the Spanish Ministry of Economy and Competitiveness, through research projects AGL2014-51964-C2-1-R and AGL2014-51964-C2-2-R. The work of JR was funded by the Secretaría Nacional de Educación Superior, Ciencia, Tecnología e Invovación of Ecuador (SENESCYT) [Grant 2013-AR3R1676]. The main author also thanks COST Action FP1206 EuMIXFOR for funding STSM FP1206-29214. We would like to thank Cristóbal Ordoñez, Jorge Aldea, Nicolás Cattaneo, Ana I. de Lucas and people of the Sustainable Forest Management Research Institute (University of Valladolid \& INIA) who have been involved in the planning, establishment, and measurement of the field experiments used in this study. We further wish to thank the Regional Forest Service of Burgos and Soria for support with field work.

\section{Appendix A. Supplementary material}

Supplementary data associated with this article can be found, in the online version, at http://dx.doi.org/10.1016/j.foreco.2017.09.036.

\section{References}

Aldea, J., Martínez-Peña, F., Romero, C., Diaz-Balteiro, L., 2014. Participatory goal programming in forest management: an application integrating several ecosystem services. Forests 5, 3352-3371.

Amoroso, M.M., Turnblom, E.C., 2006. Comparing productivity of pure and mixed Douglas-fir and western hemlock plantations in the Pacific Northwest. Can. J. For. Res. $36,1484-1496$

Binkley, D., Campoe, O.C., Gspaltl, M., Forrester, D.I., 2013. Light absorption and use efficiency in forests: why patterns differ for trees and stands. For. Ecol. Manage. 288, 5-13.

Binkley, D., Kashian, D.M., Boyden, S., Kaye, M.W., Bradford, J.B., Arthur, M.A., Fornwalt, P.J., Ryan, M.G., 2006. Patterns of growth dominance in forests of the Rocky Mountains USA. For. Ecol. Manage. 236, 193-201.

Bourdier, T., Cordonnier, T., Kunstler, G., Piedallu, C., Lagarrigues, G., Courbaud, B., 2016. Tree size inequality reduces forest productivity: an analysis combining inventory data for ten European species and a light competition model. PLoS One 11, 1-14.

Bravo-Oviedo, A., del Río, M., Montero, G., 2007. Geographic variation and parameter assessment in generalized algebraic difference site index modelling. For. Ecol. Manage. 247, 107-119.

Bunn, A.G., 2010. Statistical and visual crossdating in R using the dplR library. Dendrochronologia 28, 251-258

Cattaneo, N., Bravo-Oviedo, A., del Río, M., Riofrío, J., Bravo, F., 2017. Eficiencia de crecimiento en pinares mixtos mediterráneos. In: 7th Spanish Forestry Congress. Plascencia-Spain.

Cocozza, C., Palombo, C., Tognetti, R., Porta, N.La, Anichini, M., Giovannelli, A., Emiliani, G., 2016. Monitoring intra-annual dynamics of wood formation with microcores and dendrometers in Picea abies at two different altitudes. Tree Physiol. 36, 832-846.

Dănescu, A., Albrecht, A.T., Bauhus, J., 2016. Structural diversity promotes productivity of mixed, uneven-aged forests in southwestern Germany. Oecologia 182, 319-333.

del Río, M., Montero, G., Bravo, F., 2001. Analysis of diameter - density relationships and self-thinning in non-thinned even-aged Scots pine stands. For. Ecol. Manage. 142, 79-87.

del Río, M., Pretzsch, H., Alberdi, I., Bielak, K., Bravo, F., Brunner, A., Condés, S., Ducey, M.J., Fonseca, T., von Lüpke, N., Pach, M., Peric, S., Perot, T., Souidi, Z., Spathelf, P., Sterba, H., Tijardovic, M., Tomé, M., Vallet, P., Bravo-Oviedo, A., 2016. Characterization of the structure, dynamics, and productivity of mixed-species stands: review and perspectives. Eur. J. For. Res. 135, 23-49.

del Río, M., Pretzsch, H., Ruíz-Peinado, R., Ampoorter, E., Annighofer, P., Barbeito, I., Bielak, K., Brazaitis, G., Coll, L., Drossler, L., Fabrika, M., Forrester, D.I., Heym, M., Hurt, V., Kurylyak, V., Lof, M., Lombardi, F., Madrickiene, E., Matovic, B., Mohren, F., Motta, R., den Ouden, J., Pach, M., Ponette, Q., Schutze, G., Skrzyszewski, J., Sramek, V., Sterba, H., Stojanovic, D., Svoboda, M., Zlatanov, T.M., Bravo-Oviedo, A., 2017. Species interactions increase the temporal stability of community productivity in $\mathrm{Pi}$ nus sylvestris-Fagus sylvatica mixtures across Europe. J. Ecol. 105, 1032-1043. del Río, M., Schütze, G., Pretzsch, H., 2014. Temporal variation of competition and facilitation in mixed species forests in Central Europe. Plant Biol. 16, 166-176.

Dirnberger, G., Sterba, H., Condés, S., Ammer, C., Annighöfer, P., Avdagić, A., Bielak, K. Brazaitis, G., Coll, L., Heym, M., Hurt, V., Kurylyak, V., Motta, R., Pach, M., Ponette, Q., Ruiz-Peinado, R., Skrzyszewski, J., Srámek, V., de Streel, G., Svoboda, M., Zlatanov, T., Pretzsch, H., 2017. Species proportions by area in mixtures of Scots pine (Pinus sylvestris L.) and European beech (Fagus sylvatica L.). Eur. J. For. Res. 136, 171-183.

Eilmann, B., Zweifel, R., Buchmann, N., Pannatier, E.G., Rigling, A., 2011. Drought alters timing, quantity, and quality of wood formation in Scots pine. J. Exp. Bot. 62 , 2763-2771.

Forrester, D.I., 2014. The spatial and temporal dynamics of species interactions in mixed-species forests: from pattern to process. For. Ecol. Manage. 312, 282-292.

Forrester, D.I., Ammer, C., Annighöfer, P.J., Barbeito, I., Bielak, K., Bravo-Oviedo, A., Coll, L., del Río, M., Drössler, L., Heym, M., Hurt, V., Löf, M., den Ouden, J., Pach, M., Pereira, M.G., Plaga, B.N.E., Ponette, Q., Skrzyszewski, J., Sterba, H., Svoboda, M., Zlatanov, T., Pretzsch, H., 2017a. Effects of crown architecture and stand structure on light absorption in mixed and monospecific Fagus sylvatica and Pinus sylvestris forests along a productivity and climate gradient through Europe. J. Ecol.

Forrester, D.I., Benneter, A., Bouriaud, O., 2017. Diversity and competition influence tree allometric relationships - developing functions for mixed-species forests. J. Ecol. 105, 761-774.

Forrester, D.I., Pretzsch, H., 2015. Tamm Review: On the strength of evidence when comparing ecosystem functions of mixtures with monocultures. For. Ecol. Manage. 356, 41-53.

Gadow, K.v., Zhang, C.Y., Wehenkel, C., Pommerening, A., Corral-Rivas, J., Korol, M., Myklush, S., Ying Hui, G., Kiviste, A., Zhao, X.H., 2012. Forest Structure and Diversity. In: Pukkala, T., von Gadow, K. (Eds.), Continuous Cover Forestry, Book Series Managing Forest Ecosys-Tems. Springer, Berlin, pp. 29-84.

Gaudio, N., Balandier, P., Perret, S., Ginisty, C., 2011. Growth of understorey Scots pine (Pinus sylvestris L.) saplings in response to light in mixed temperate forest. Forestry 84, 187-195.

Gómez-Aparicio, L., García-Valdés, R., Ruíz-Benito, P., Zavala, M.A., 2011. Disentangling the relative importance of climate, size and competition on tree growth in Iberian forests: implications for forest management under global change. Glob. Chang. Biol. $17,2400-2414$

Gratani, L., 2014. Plant phenotypic plasticity in response to environmental factors. Adv Bot. 2014, 17.

Ishii, H., Asano, S., 2010. The role of crown architecture, leaf phenology and photosynthetic activity in promoting complementary use of light among coexisting species in temperate forests. Ecol. Res. 25, 715-722.

Jucker, T., Bouriaud, O., Avacaritei, D., Dănilă, I., Duduman, G., Valladares, F., Coomes, D.A., 2014. Competition for light and water play contrasting roles in driving diversity-productivity relationships in Iberian forests. J. Ecol. 102, 1202-1213.

Jucker, T., Bouriaud, O., Coomes, D.A., 2015. Crown plasticity enables trees to optimize canopy packing in mixed-species forests. Funct. Ecol. 29, 1078-1086.

Lara, W., Bravo, F., Maguire, D.A., 2013. Modeling patterns between drought and tree biomass growth from dendrochronological data: a multilevel approach. Agric. For. Meteorol. 178-179, 140-151.

Lara, W., Bravo, F., Sierra, C.a., 2015. measuRing: an R package to measure tree-ring widths from scanned images. Dendrochronologia 34, 43-50.

Larocque, G.R., Luckai, N., Adhikary, S.N., Groot, A., Bell, F.W., Sharma, M., 2013. Competition theory - science and application in mixed forest stands: future research. Environ. Rev. 84, 71-84.

Lizarralde, I., 2008. Dinámica de rodales y competencia en las masas de Pino silvestre (Pinus sylvestris L.) y Pino negral (Pinus pinaster Ait.) de los Sistemas Central e Ibérico meridional. Universidad de Valladolid.

López Marcos, D., Martínez-Ruiz, C., Turrión Nievez, M., Bravo, F., 2017. Influencia de la composición del estrato arbóreo en el secuestro de carbono edafico. In: 7th Spanish Forestry Congress. Plascencia-Spain, p. 7CFE01-158.

Mainwaring, D.B., Maguire, D.A., 2004. The effect of local stand structure on growth and growth efficiency in heterogeneous stands of ponderosa pine and lodgepole pine in central Oregon. Can. J. For. Res. 34, 2217.

McElhinny, C., Gibbons, P., Brack, C., Bauhus, J., 2005. Forest and woodland stand structural complexity: Its definition and measurement. For. Ecol. Manage. 218, 1-24.

Menalled, F.D., Kelty, M.J., Ewel, J.J., 1998. Canopy development in tropical tree plantations: a comparison of species mixtures and monocultures. For. Ecol. Manage. 104, 249-263.

Poorter, L., Lianes, E., Moreno-de las Heras, M., Zavala, M.A., 2012. Architecture of Iberian canopy tree species in relation to wood density, shade tolerance and climate. Plant Ecol. 213, 707-722.

Pretzsch, H., 2009. Forest Dynamics. Growth and Yield, Springer, Berlin Heidelberg, Berlin, Heidelberg

Pretzsch, H., 2014. Canopy space filling and tree crown morphology in mixed-species stands compared with monocultures. For. Ecol. Manage. 327, 251-264.

Pretzsch, H., Biber, P., 2016. Tree species mixing can increase maximum stand density. Can. J. For. Res. 1-15.

Pretzsch, H., Block, J., Dieler, J., Dong, P.H., Kohnle, U., Nagel, J., Spellmann, H., Zingg, A., 2010. Comparison between the productivity of pure and mixed stands of Norway spruce and European beech along an ecological gradient. Ann. For. Sci. 67, 712.

Pretzsch, H., del Río, M., Ammer, C., Avdagic, A., Barbeito, I., Bielak, K., Brazaitis, G., Coll, L., Dirnberger, G., Drössler, L., Fabrika, M., Forrester, D.I., Godvod, K., Heym, M., Hurt, V., Kurylyak, V., Löf, M., Lombardi, F., Matović, B., Mohren, F., Motta R., den Ouden, J., Pach, M., Ponette, Q., Schütze, G., Schweig, J., Skrzyszewski, J., Sramek, V., Sterba, H., Stojanović, D., Svoboda, M., Vanhellemont, M., Verheyen, K. Wellhausen, K., Zlatanov, T., Bravo-Oviedo, A., 2015. Growth and yield of mixed versus pure stands of Scots pine (Pinus sylvestris L.) and European beech (Fagus sylvat- 
ica L.) analysed along a productivity gradient through Europe. Eur. J. For. Res. 134, 927-947.

Pretzsch, H., del Río, M., Schütze, G., Ammer, C., Annighöfer, P., Avdagic, A., Barbeito, I., Bielak, K., Brazaitis, G., Coll, L., Drössler, L., Fabrika, M., Forrester, D.I., Kurylyak, V., Löf, M., Lombardi, F., Matović, B., Mohren, F., Motta, R., den Ouden, J., Pach, M., Ponette, Q., Skrzyszewski, J., Sramek, V., Sterba, H., Svoboda, M., Verheyen, K., Zlatanov, T., Bravo-Oviedo, A., 2016. Mixing of Scots pine (Pinus sylvestris L.) and European beech (Fagus sylvatica L.) enhances structural heterogeneity, and the effect increases with water availability. For. Ecol. Manage. 373, 149-166.

Pretzsch, H., Forrester, D.I., Rötzer, T., 2015. Representation of species mixing in forest growth models. A review and perspective. Ecol. Modell. 313, 276-292.

Pretzsch, H., Schütze, G., 2009. Transgressive overyielding in mixed compared with pure stands of Norway spruce and European beech in Central Europe: evidence on stand level and explanation on individual tree level. Eur. J. For. Res. 128, 183-204.

Pretzsch, H., Schütze, G., 2016. Effect of tree species mixing on the size structure, density, and yield of forest stands. Eur. J. For. Res. 135, 1-22.

Pretzsch, H., Schütze, G., Uhl, E., 2013. Resistance of European tree species to drought stress in mixed versus pure forests: evidence of stress release by inter-specific facilitation. Plant Biol. 15, 483-495.

R Develomment Core Team, 2015. R: A language and environment for statistical computing. R Found. Stat. Comput.

Reineke, L., 1933. Perfecting a stand-density index for even-aged forests. J. Agric. Res. 46, 627-638.

Riofrío, J., del Río, M., Aldea, J., Bravo, F., 2017a. Relaciones de complementariedad en masa mixtas de pinos mediterráneos: un análisis de los patrones de incremento radial intra-annual. In: 7th Spanish Forestry Congress. Plascencia-Spain.

Riofrío, J., del Río, M., Bravo, F., 2017. Mixing effects on growth efficiency in mixed pine forests. Forestry 90, 381-392.

Rodríguez, F., Broto, M., 2014. Ecuaciones de volumen comencial para las principales especies maderables de Castillas y León.
Rojo, A., Montero, G., 1996. El pino silvestre en la Sierra de Guardarrama. Ministerio de Agricultura, Pesca y Alimentación, Madrid - España.

Sánchez-Gómez, D., Valladares, F., Zavala, M.A., 2006. Functional traits and plasticity in response to light in seedlings of four Iberian forest tree species. Tree Physiol. 26, 1425-1433.

Sterba, H., del Río, M., Brunner, A., Condes, S., 2014. Effect of species proportion definition on the evaluation of growth in pure vs. mixed stands. For. Syst. 23, 547-559.

Swidrak, I., Schuster, R., Oberhuber, W., 2013. Comparing growth phenology of co-occurring deciduous and evergreen conifers exposed to drought. Flora Morphol. Distrib. Funct. Ecol. Plants 208, 609-617.

Toïgo, M., Perot, T., Courbaud, B., Castagneyrol, B., Gégout, J.-C., Longuetaud, F., Jactel, H., Vallet, P., 2017. Difference in shade tolerance drives the mixture effect on oak productivity. J. Ecol.

Toïgo, M., Vallet, P., Perot, T., Bontemps, J.-D., Piedallu, C., Courbaud, B., 2015. Overyielding in mixed forests decreases with site productivity. J. Ecol. 103, 502-512.

Valladares, F., Chico, J.M., Aranda, I., Balaguer, L., Dizengremel, P., Manrique, E., Dreyer, E., 2002. The greater seedling high-light tolerance of Quercus robur over Fagus sylvatica is linked to a greater physiological plasticity. Trees-Struct. Funct. 16, 395-403.

Vallet, P., Perot, T., 2016. Tree diversity effect on dominant height in temperate forest. For. Ecol. Manage. 381, 106-114.

Vizcaíno-Palomar, N., Ibañez, I., González-Martínez, S.C., Zavala, M.A., Alía, R., 2016. Adaptation and plasticity in aboveground allometry variation of four pine species along environmental gradients. Ecol. Evol. 6, 7561-7573.

Warton, D.I., Duursma, R.A., Falster, D.S., Taskinen, S., 2012. smatr 3- an R package for estimation and inference about allometric lines. Methods Ecol. Evol. 3, 257-259.

Warton, D.I., Wright, I.J., Falster, D.S., Westoby, M., 2006. Bivariate line-fitting methods for allometry. Biol. Rev. 81, 259-291.

Williams, L.J., Paquette, A., Cavender-Bares, J., Messier, C., Reich, P.B., 2017. Spatial complementarity in tree crowns explains overyielding in species mixtures. Nat. Ecol. Evol. 1,63 . 